\title{
Analisis Performansi Multi User Detection pada Kanal NLOS untuk Sistem NOMA-VLC
}

\author{
BIMA SURYA PRATAMA, NACHWAN MUFTI ADRIANSYAH, BRIAN PAMUKTI
}

\author{
Telkom University, Indonesia
}

Email: bsurya1923@gmail.com

Received 1 Oktober 2020 | Revised 20 Oktober 2020 | Accepted 15 November 2020

\begin{abstract}
ABSTRAK
Non-orthogonal multiple access (NOMA), mulai diteliti untuk dapat digunakan sebagai teknik multiple access yang efektif pada jaringan $5 G$ karena teknik ini dapat menghemat bandwidth modulasi. Pada penelitian ini, NOMA diterapkan untuk sistem downlink Visible Light Communivation (VLC). Kami telah melakukan analisis performansi Multi-User Detection (MUD) pada kanal propagasi Non-Line of Sight (NLOS) dengan mempertimbangkan efek reflektor dan efek bayangan (shadowing). Kami juga mempertimbangkan teknik MUD yang digunakan pada penelitian ini yaitu Succesive Interference Cancellation (SIC). Setelah simulasi yang ekstensif, kami menemukan bahwa dengan penerapan SIC sebagai MUD pada sistem NOMA-VLC lebih baik dibandingkan dengan tanpa NOMA. Selain itu, kami juga memperoleh peningkatan data rate sebesar $72 \%$.
\end{abstract}

Kata kunci: VLC, NOMA, NLOS, MUD, Optical Wireless Communication.

\begin{abstract}
Non-orthogonal multiple access (NOMA), began to be studied to be used as an effective multiple access technique on $5 G$ networks because this technique can save modulation bandwidth. In this research, NOMA is applied to the Visible Light Communivation (VLC) downlink system. We have performed a Multi-User Detection (MUD) performance analysis on Non-Line of Sight (NLOS) propagation channels by considering the reflector and shadowing effects. We also consider the MUD technique used in this study, namely Successive Interference Cancellation (SIC). After extensive simulations, we found that the application of SIC as MUD to the NOMA-VLC system is better than without NOMA. In addition, we also achieve an increase in data rate of $72 \%$.
\end{abstract}

Keywords: VLC, NOMA, NLOS, MUD, Optical Wireless Communication. 


\section{PENDAHULUAN}

Diera revolusi industri 4.0, kebutuhan akan teknologi komunikasi dan informasi semakin tinggi. Hal ini berpengaruh pada bidang telekomunikasi khususnya pada komunikasi dengan media berupa kabel maupun nirkabel. Kebutuhan akan teknologi yang semakin meningkat ini berdampak pada keterbatasan sumber daya yang ada, salah satunya yaitu keterbatasan spektrum frekuensi yang digunakan dalam pengiriman data nirkabel pada sistem telekomunikasi. Teknologi Optical Wireless Communication (OWC) merupakan salah satu solusi yang dapat digunakan untuk mengatasi permasalahan tersebut, karena teknologi ini dapat menghemat spektrum frekuensi dengan tetap menghasilkan data rate yang tinggi (Ghassemlooy, dkk, 2019). Visible Light Communication (VLC) adalah salah satu penerapan dari teknologi OWC dengan menggunakan Light Emmiting Diode (LED) sebagai sumber pengiriman cahaya dan memanfaatkan panjang gelombang sebesar 380-780 nm. Namun, modulasi yang terbatas menjadi keterbatasan utama pada VLC (Wang, dkk, 2015). VLC mampu menjadi alternatif bagi Wireless Fidelity (WiFi) sebagai jaringan akses hingga ke pelanggan. Seperti yang sudah diteliti oleh (Tonapa, dkk, 2014) bahwa wireless untuk broadband memiliki Quality of Service (QoS) yang tinggi. Hal ini membuat VLC bisa meningkatkan nilai QoS jauh lebih tinggi dari WiFi.

Orthogonal Frequency Division Multiplexing (OFDM) dan Orthogonal Frequency Division Multiple Access (OFDMA) diterapkan dalam sistem VLC dikarenakan efisiensi spektral yang tinggi (Armstrong, dkk, 2012). Namun, teknik OFDM dan OFDMA tidak dapat langsung diterapkan dalam sistem VLC, karena sinyal yang dapat dibaca pada modulasi VLC hanya sinyal real dan positif sesuai persyaratan pencahayaan. Oleh karena itu, teknik clipping telah diusulkan untuk diadaptasi dalam OFDM dan OFDMA sistem VLC, tetapi teknik tersebut dapat menurunkan efisiensi spektral dan kinerja Bit Error Rate (BER) (Dimitrov, dkk, 2012).

Untuk mengatasi masalah bandwidth moduasi pada VLC yang terbatas, Non-Orthogonal Multiple Access (NOMA) baru-baru ini diusulkan sebagai kandidat multiple access yang menjanjikan untuk jaringan nirkabel $5 \mathrm{G}$ (Benjebbour, dkk, 2013) karena dapat menghemat bandwidth modulasi. Dalam penelitian (Su, dkk, 2016) diterapkan NOMA pada sistem downlink VLC, didapatkan hasil bahwa NOMA dapat meningkatkan data rate yang dicapai sistem VLC. Pada NOMA, sinyal yang ditransmisikan dari multi-user menghasilkan interferensi antar user (Marshoud, dkk, 2015), maka dibutuhkan teknik Multi-User Detection (MUD) untuk mendeteksi sinyal yang diterima pada setiap user (Guan, dkk, 2017). Proses multiplexing dengan menggunakan NOMA dilakukan dalam domain daya dengan adanya superimposed di sisi transmitter dan MUD di sisi receiver. Untuk mengembangkan VLC, penelitian ini melakukan penelitian terhadap performansi MUD pada kanal NLOS untuk sistem NOMA-VLC.

Penelitian (Putri dkk, 2019) telah mengerjakan tentang penggunaan penguat optik dengan konsentrator untuk komunikasi cahaya tampak. Jurnal tersebut menemukan cakupan area komunikasi yang dapat dijangkau oleh lampu LED. Kami juga menganalisis bahwa jurnal ini hanya membahas satu sisi, yaitu pada downlink. Dari penelitian tersebut, diperoleh hasil bahwa penggunaan kosentrator pada penerima, meningkatkan performansi dan menurunkan nilai Bit Error Rate(BER). Selain itu, penelitian ini belum membahas pembagian Multiple Access (MA).

Penelitian (Kurniawan dkk, 2019) membahas tentang perbedaan teknik modulasi pada kanal Visible Light Communication (VLC). Penelitian tersebut menggunakan dua modulasi, yaitu Return-to-Zero (RZ) dan Non Return-to-Zero (NRZ) dengan line coding On-Off Keying (OOK). Model ruangan yang digunakan adalah $5 \times 5 \times 3 \mathrm{~m}^{3}$ dengan tidak mempertimbangkan 
interferensi matahari. Hasil penelitian tersebut membuktikan bahwa modulasi NRZ-OOK lebih baik dibandingkan modulasi RZ-OOK.

NOMA membutuhkan teknik untuk pengalokasian daya setiap user, terdapat resource management yang mirip dengan power alokasi yaitu water filling cara kerjanya user yang memiliki nilai Signal to Noise Ratio (SNR) tinggi akan dialokasikan daya yang rendah, sedangkan user yang memiliki SNR rendah akan dialokasikan daya yang lebih tinggi agar semua user mendapatkan kualitas yang sama serta karena orthogona/maka semua userdapat dideteksi. Namun, NOMA adalah teknik multiple acces yang non-orthogonal mengakibatkan user rawan tidak terdeteksi. Penelitian ini menerapkan Gain Ratio Power Allocation (GRPA) sebagai teknik pengalokasian daya karena GRPA dapat mempertimbangkan proses SIC untuk mendeteksi sinyal. GRPA dapat menyelesaikan permasalahan useryang rawan tidak terdeteksi pada NOMA dengan cara mengurutkan user terlebih dahulu kemudian power dialokasikan berdasarkan rasio gain yang didapat dari kondisi kanal yang dimiliki oleh setiap user dan GRPA secara signifikan dapat meningkatkan kinerja sistem menjadikan sum rate maksimal.

Pada beberapa penelitian sebelumnya diterapkan Succesive Interference Cancellation (SIC) sebagai MUD pada sistem NOMA-VLC. Teknik ini digunakan pada karakteristik kanal Line of Sight (LOS) dan dihasilkan performansi yang lebih baik dibandingkan penggunaan teknik multiple access lainnya pada VLC. Pada Penelitian ini diterapkan SIC sebagai MUD dalam NOMA-VLC dengan kanal yang digunakan yaitu Non-Line of Sight(NLOS) dengan penambahan efek reflektor dan bayangan karena pada realisasi ruangan umumnya tidak ada karakteristik ruangan LOS. Adapun output yang diharapkan dari penelitian ini adalah menunjukkan hasil bahwa NOMA dapat meningkatkan kapasitas kanal dan mengatasi bandwidth modulasi yang terbatas pada sistem VLC.

\section{METODOLOGI}

\subsection{Blok Diagram Keseluruhan}

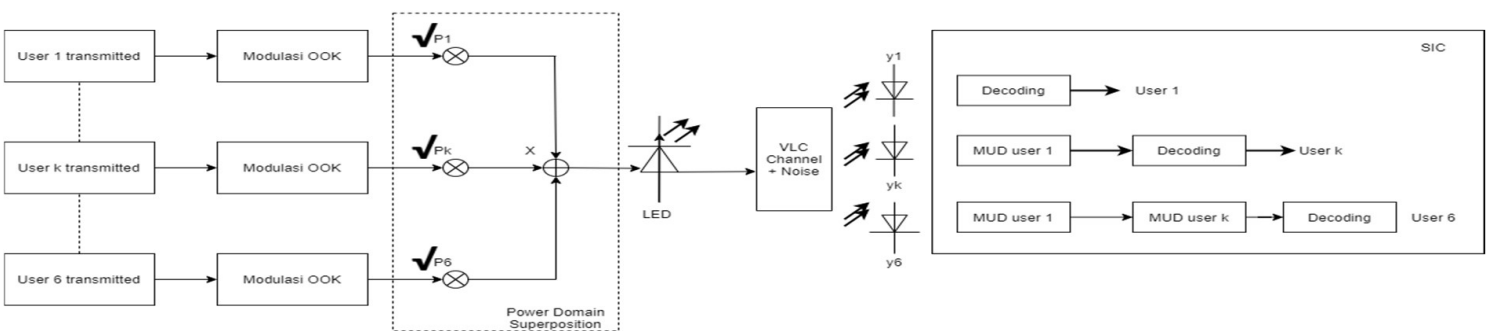

Gambar 1. Blok Diagram Sistem.

Dalam penelitian ini dilakukan perancangan sistem VLC untuk menganalisis dampak yang terjadi terhadap performansi multi-user detection dengan kanal NLOS dalam penerapan teknik multiple access yaitu Power Domain-NOMA yang terinspirasi dari (Liu, dkk, 2018). Berdasarkan Gambar 1, terdapat tiga bagian yang menyusun sistem VLC yaitu transmitter yang berisikan: sumber informasi, modulasi dan teknik superimposed. Lalu ada kanal NLOS, dan receiver yang berisi: SIC, MUD, proses decoding dan output. Pada skema VLC dengan menggunakan NOMA sebagai teknik multiple access, terdapat superimposed di sisi transmitter dan multi-user detection di sisi receiver. Dalam skema penelitian ini MUD yang digunakan yaitu Succesive Interference Cancellation (SIC). 


\subsection{Blok Diagram Transmitter}

Pada sisi transmitter menggunakan NOMA pada VLC terdapat superimposed yang bertujuan untuk menggabungkan beberapa sinyal yang sebelumnya telah dilakukan alokasi daya menggunakan algoritma Gain Ratio Power Allocation (GRPA) seperti yang telah diteliti oleh (Tao, dkk, 2019). Dengan menggunakan GRPA, kondisi channel gain setiap user menjadi pertimbangan untuk memberikan alokasi daya yang berbeda. Alokasi daya yang dikirim akan besar jika channel gain usertersebut kecil, dan alokasi daya yang kecil akan dikirimkan apabila channel gain pada user tersebut lebih besar. Sumber cahaya yang digunakan pada penelitian ini berasal dari lampu LED yang mentransmisikan data dengan daya yang dikirimkan sebesar 7 Watt.

\subsection{Blok Diagram Kanal}

Pada bagian kanal terdapat tiga kondisi yang digunakan pada penelitian ini. Pertama kondisi kanal LOS, dalam kondisi ini terdapat dua user dengan posisi yang telah ditentukan. Kedua, model kanal NLOS dengan penambahan reflektor diberikan untuk dua buah user dengan posisi yang telah ditentukan. Ketiga, kondisi kanal NLOS dengan adanya penghalang (blocking) untuk dua user yang telah ditentukan jaraknya. Kondisi tersebut kami peroleh dari penelitian (Játiva, dkk, 2020) dengan mempertimbangkan model kanal yang serupa.

\subsection{Blok Diagram Receiver}

Bagian ini menjelaskan perancangan sistem yang berada pada sisi receiver. Terdapat photodetector yang digunakan untuk menerima sinyal cahaya dari LED dan mengubahnya menjadi sinyal elektrik. Photodetector yang digunakan pada penelitian ini adalah Positive Intrinsik Negative (PIN). Lalu, terdapat Multi-User Detection (MUD) yang berupa Succesive Interference Cancellation (SIC) yang merupakan suatu teknik pendeteksi sinyal user dan pendemodulasian sinyal terima tanpa terjadinya tabrakan antar sinyal sebelum proses decoding sinyal. Cara kerja SIC yaitu dengan menyeleksi sinyal yang terkuat terlebih dahulu dan kemudian sinyal tersebut dibatalkan untuk dapat diteruskan pada proses decoding sinyal. Kami memperoleh model matematika yang mirip dan telah disimulasikan dari penelitian (B. Wang, dkk, 2016) untuk blok penerima.

\subsection{VLC Channel}

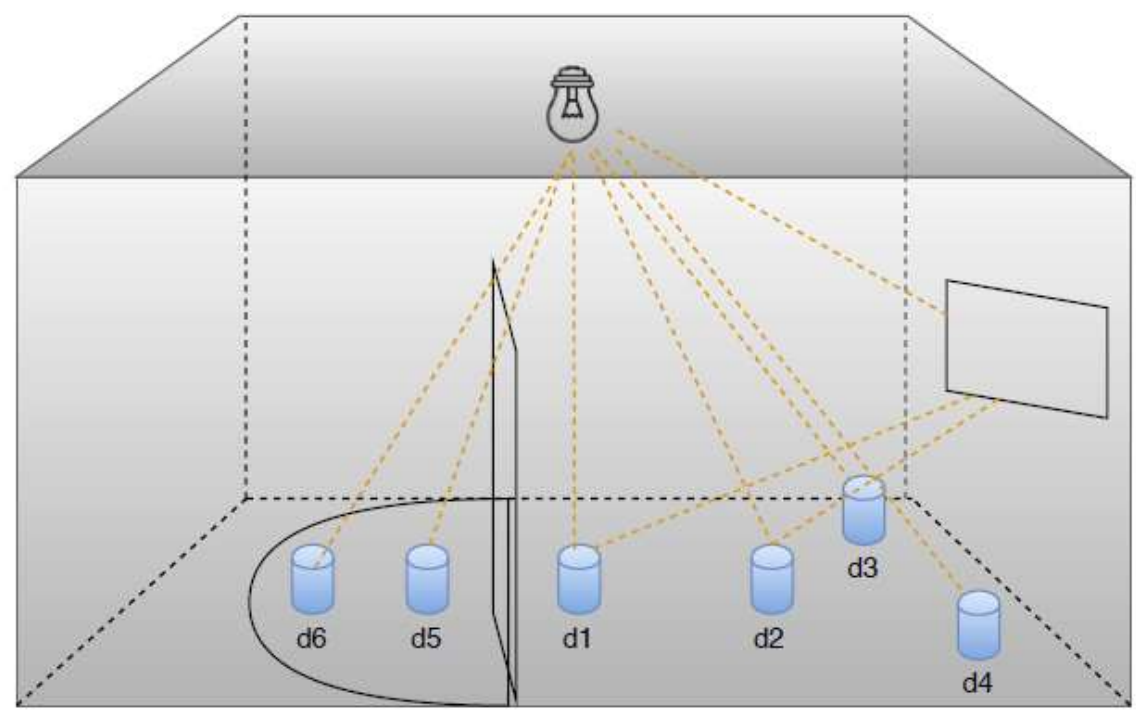

Gambar 2. Desain Ruangan NOMA-VLC dengan Kanal NLOS. 
Simulasi ini digunakan pada ruangan tertutup berukuran $5 \times 5 \times 3 \mathrm{~m}^{3}$ dengan pertimbangan tidak ada interferensi dari cahaya lain selain lampu LED. Pada skema ruangan, diletakkan cermin di salah satu sisi ruangan dan benda yang menghalangi cahaya dari lampu LED. Kami juga mempertimbangkan bahwa benda yang menjadi penghalang tidak bergerak. Selain itu, kami menggunakan distribusi Binomial untuk menandakan bahwa benda tersebut menyerap daya optis (absorption effect). Jika benda tersebut menyerap cahaya LED 100\%, maka nilai dari distribusi Binomial adalah nol dan jika tidak ada benda yang menghalangi, maka distribusi Binomial bernilai satu.

Berdasarkan karakteristik saluran VLC, sinyal yang diterima oleh user pada umumnya terdiri dari dua komponen LOS dan NLOS. Pada penelitian ini berfokus pada kanal NLOS dengan penambahan reflektor dan efek bayangan. Kanal LOS memiliki tingkat kesalahan bit yang lebih rendah dan protokol yang tidak terlalu rumit, namun terbatas dalam segi mobilitas. parameter lambertian $(\mathrm{m})$ yang mana memiliki hubungan dengan semi-angle dengan $\theta$ yang memiliki nilai sebesar 70 dinyatakan dengan :

$$
m=\frac{-\log _{10} 2}{\log _{10} \cos \theta_{\overline{1}}}
$$

Pada kanal LOS dapat dinyatakan dengan :

$$
H_{L O S}=\frac{(m+1) \cdot A e \cdot \cos \Phi^{m+1}}{2 \cdot \pi \cdot d^{2}},
$$

Dengan Ae adalah area photodetector pada penerima, $\mathrm{d}$ adalah jarak penerima terhadap pengirim, dan $\Phi$ adalah sudut propagasi dari pengirim dengan penerima. Kanal yang digunakan pada penelitian ini adalah kanal NLOS. Pada kanal NLOS nilai pathloss yang didapat lebih sulit untuk dikalkulasikan karena bergantung pada banyak faktor, yaitu dimensi ruangan, pantulan dari langit-langit ruangan, objek yang berada di dalam ruangan serta posisi dan orientasi transmitter dan receiver. Pada penelitian ini menggunakan obstacle berupa reflektor dan efek bayangan yang dihasilkan oleh blockage di photodetector. Kanal dengan penambahan efek bayangan dapat dinyatakan dengan Persamaan (3).

$$
H_{\text {shd }}=\frac{(m+1) \cdot A e \cdot \cos ^{m+1}(\Phi)}{2 \cdot \pi \cdot d^{2}} \times O,
$$

Dengan $O$ adalah probabilitas blocking, dengan asumsi pengurangan daya mengikuti distribusi binomial di mana dari daya yang dikirim setelah terkena blockage, daya diteruskan ke shadowing area kemudian dilanjutkan ke photodetector. Untuk kanal reflector dinyatakan dengan Persamaan (4).

$$
H_{\text {ref }}=\frac{(m+1) \cdot A e \cdot \rho \cdot d A \cdot \cos ^{m+1}(\Phi) \cdot \cos \alpha \cdot \cos \beta}{2 \cdot \pi \cdot d_{1}^{2} \cdot d_{2}^{2}}
$$

Dengan $A e$ sebagai area photodetector dan $\mathrm{d}_{1}$ adalah jarak dari transmitter ke reflektor, $\mathrm{d}_{2}$ jarak dari reflektor ke receiver, sedangkan $\rho$ merupakan koefiesien refleksi dan $d A$ merupakan luas per cell. Nilai sudut dari $\alpha$ dibentuk dari jarak antara lampu LED terhadap dinding cermin dan sudut $\beta$ dibentuk oleh jarak antara dinding cermin dan user. Sehingga channel gain total yang diperoleh user adalah : 


$$
H=H_{L O S}+H_{\text {ref }}+H_{\text {shd }}
$$

\subsection{Sistem NOMA-VLC}

Dalam penelitian ini, jaringan downlink indoor NOMA-VLC dilengkapi dengan 1 buah LED dan 6 user. Melalui prinsip NOMA, userdiberi nilai daya yang berbeda tergantung pada gain saluran mereka di sisi transmitter. Sinyal yang ditransmisikan didapatkan dari persamaan (5).

$$
\alpha_{1} x P_{T}>\alpha_{k} x P_{T} \ldots>\alpha_{n} x P_{T}>\alpha_{N} x P_{T} \text {, s.t. } \sum_{k=1}^{N} \alpha_{k}=1
$$

Dengan $N$ adalah jumlah user yang berada dalam jangkauan satu buah LED. Lalu sinyal yang dikirimkan dapat dinyatakan sebagai berikut

$$
\boldsymbol{x}=\boldsymbol{P} \times\left(\sqrt{\alpha_{1} x s_{1}}+\sqrt{\alpha_{2} x s_{2}}+\sqrt{\alpha_{3} x s_{3}}+\sqrt{\alpha_{4} x s_{4}}+\sqrt{\alpha_{5} x s_{5}}+\sqrt{\alpha_{6} x s_{6}}\right),
$$

dengan $P$ adalah transmit power dan $s$ adalah sinyal yang dikirimkan. Penelitian ini menggunakan metode Multi-User Detection (MUD) untuk mendeteksi daya yang diterima dari semua pengguna adalah tetap, sekaligus mendemodulasikan semua sinyal yang diterima dari semua pengguna secara bersamaan. Maka memerlukan strategi MUD yang sesuai seperti Succesive Interference Cancellation (SIC), setelah menerima sinyal penerima mendeteksi dan mendekodekan sinyal dari beberapa pemancar dengan urutan kekuatan sinyal yang menurun. Untuk perhitungan SIC dapat dinyatakan dengan Persamaan (7).

$$
P r_{s i c}=y_{n}-\sqrt{H_{n}} \times\left(\sqrt{\alpha_{-} k}+\cdots+\sqrt{\alpha_{-} k-1}\right)
$$

Dengan $y_{n}$ adalah sinyal terima oleh user ke-n, dan $H_{n}$ adalah channel gain dan $\alpha_{k}$ adalah nilai alokasi power dari setiap user. Sehingga daya terima yang sudah di SIC mengalami pengurangan sedikit demi sedikit.

\subsection{Validasi Data}

\subsubsection{Signal to Noise Ratio (SNR)}

Signal to Noise Ratio (SNR) merupakan perbandingan daya sinyal yang ditransmisikan dengan daya noise yang terdapat pada sistem. Nilai receive SNR didapatkan dari Persamaan (8).

$$
S N R=\frac{\left(P_{r} R M\right)^{2}}{2 q P_{r} R M^{2} F(M) B+\frac{4 K_{b} T B}{R_{l}}}
$$

Dengan $R$ adalah responsivitas, Madalah multiplikasi, $q$ adalah muatan listrik $F(M)$ adalah noise figure, $K_{b}$ adalah konstanta Boltzmann, $T$ adalah suhu detector foto, $B$ adalah

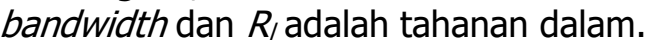

\subsubsection{Data Rate}

Data rate merupakan bit data yang dapat diterima dengan benar dalam satuan waktu. Data rate maksimal dapat diperoleh dengan perhitungan kapasitas kanal yang digunakan. Berikut adalah persamaan kapasitas kanal menggunakan teorema Shannon Capacity.

$$
C=B_{w} \times \log (1+S N R)
$$

Dengan $B_{w}$ adalah bandwidth LED. 


\section{HASIL DAN ANALISIS}

Pada bagian ini membahas tentang hasil simulasi dan analisis dalam penelitian ini dengan perancangan sistem VLC untuk menganalisis dampak yang terjadi terhadap performansi MultiUser Detection dengan kanal NLOS dalam penerapan teknik multiple access yaitu NOMA. Proses diawali dengan melakukan simulasi dengan parameter yang sudah ditentukan. Simulasi menggunakan ruangan dengan dimensi $5 \times 5 \times 3 \mathrm{~m}^{3}$. Skenario pertama membandingkan nilai channe/ gain dengan kondisi kanal tiap user, skenario kedua membandingkan nilai receive SNR VLC tanpa NOMA dengan NOMA-VLC pada setiap user dengan kanal yang berbeda, skenario ketiga membandingkan nilai data rate VLC tanpa NOMA dengan NOMA-VLC pada setiap user dengan kanal yang berbeda.

\subsection{Analisis Channe/ Gain Sistem}

Analisis ini bertujuan untuk membandingkan posisi user terhadap channel gain untuk VLC NOMA.

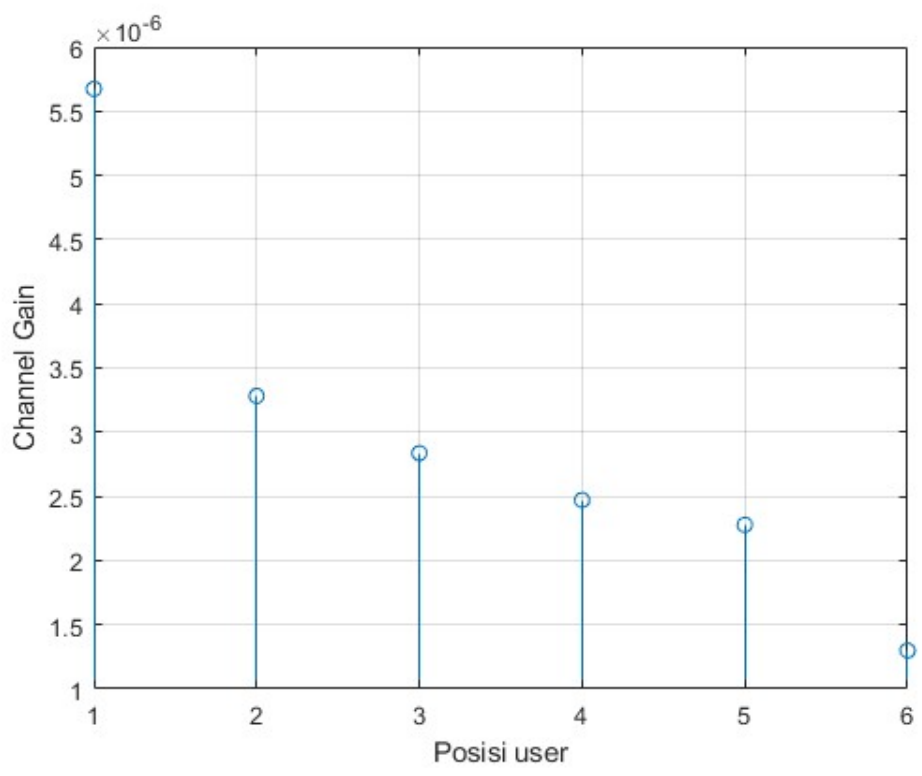

Gambar 3. Nilai Channel Gain User.

Gambar 3 menunjukan hasil channel gain yang dicapai, channe/ gain paling baik dicapai pada saat posisi user diletakkan pada kanal NLOS dengan penambahan reflektor sebesar $5.6885 \times 10^{-6}$. Sedangkan posisi user dengan kondisi kanal NLOS dengan penambahan efek bayangan menjadi channel gain yang terendah dengan nilai sebesar $1.2986 \times 10^{-6}$. Hal ini menunjukkan bahwa performansi reflektor lebih baik dibandingkan dengan efek bayangan karena user dengan reflektor menerima efek multipath yang dapat meningkatkan gain.

\subsection{Analisis Perbandingan SNR VLC Tanpa NOMA dengan NOMA-VLC}

Analisis ini bertujuan untuk membandingkan hasil SNR yang diterima pada VLC tanpa NOMA dengan NOMA-VLC. 


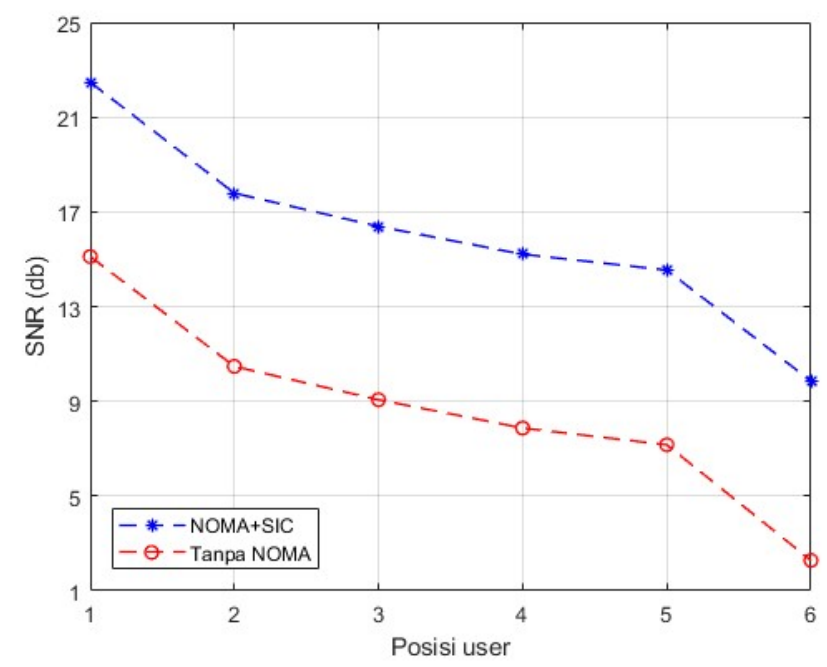

Gambar 4. Perbandingan SNR VLC Tanpa NOMA dan NOMA-VLC.

Gambar 4 menunjukkan tentang pengaruh posisi user terhadap nilai SNR dengan menggunakan NOMA dan tanpa NOMA. SNR maksimal yang dicapai pada NOMA-VLC sebesar $22.4719 \mathrm{~dB}$, sedangkan pada VLC tanpa NOMA, SNR maksimal yang dicapai sebesar 15.112 $\mathrm{dB}$. Hasil yang diperoleh pada penelitian ini menunjukkan bahwa NOMA mampu meningkatkan nilai SNR dengan peningkatan rata-rata SNR pada tiap user sebesar $7 \mathrm{~dB}$. Hal ini dikarenakan pada sistem NOMA-VLC terdapat superimposed di sisi transmitter membuat sinyal dapat dikirmkan secara bersamaan sehingga meningkatkan efisiensi spektral dan Multi-User Detection di sisi receiver membuat performansi menjadi lebih baik.

\subsection{Analisis Posisi User terhadap Data Rate}

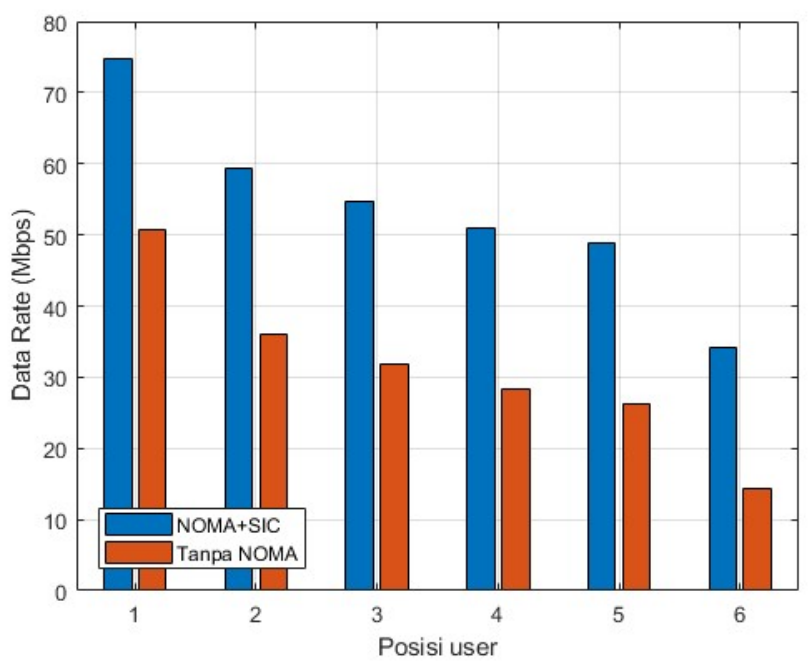

Gambar 5. Perbandingan data rate VLC Tanpa NOMA dan NOMA-VLC.

Gambar 5 menunjukkan mengenai pengaruh posisi user terhadap data rate yang didapat dengan perbandingan VLC menggunakan NOMA dan tanpa NOMA. Data rate maksimal yang dicapai pada NOMA-VLC sebesar 74.7 Mbps, sedangkan pada VCL tanpa NOMA data rate maksimal yang dicapai sebesar 50 Mbps. Hasil yang diperoleh pada penelitian ini menunjukkan 
bahwa NOMA mampu meningkatkan nilai data rate dengan peningkatan rata-rata pada tiap user sebesar 24 Mbps. Hal ini disebabkan NOMA memiliki efisiensi spektral yang tinggi karena terdapat proses superimposed di sisi pengirim dengan menggabungkan dan mengirimkan semua user secara bersamaan. Proses deteksi dilakukan MUD yang berupa SIC di sisi penerima untuk mendapatkan sinyal yang diinginkan, sehingga setiap user dapat menggunakan seluruh bandwidth yang tersedia dengan asumsi kondisi kanal tetap dan nilai receive SNR sempurna sehingga meningkatkan data rate yang diterima. Selain itu, penelitian ini membuktikan bahwa total data rate meningkat sebesar $72 \%$ dari 186 Mbps menjadi 321 Mbps.

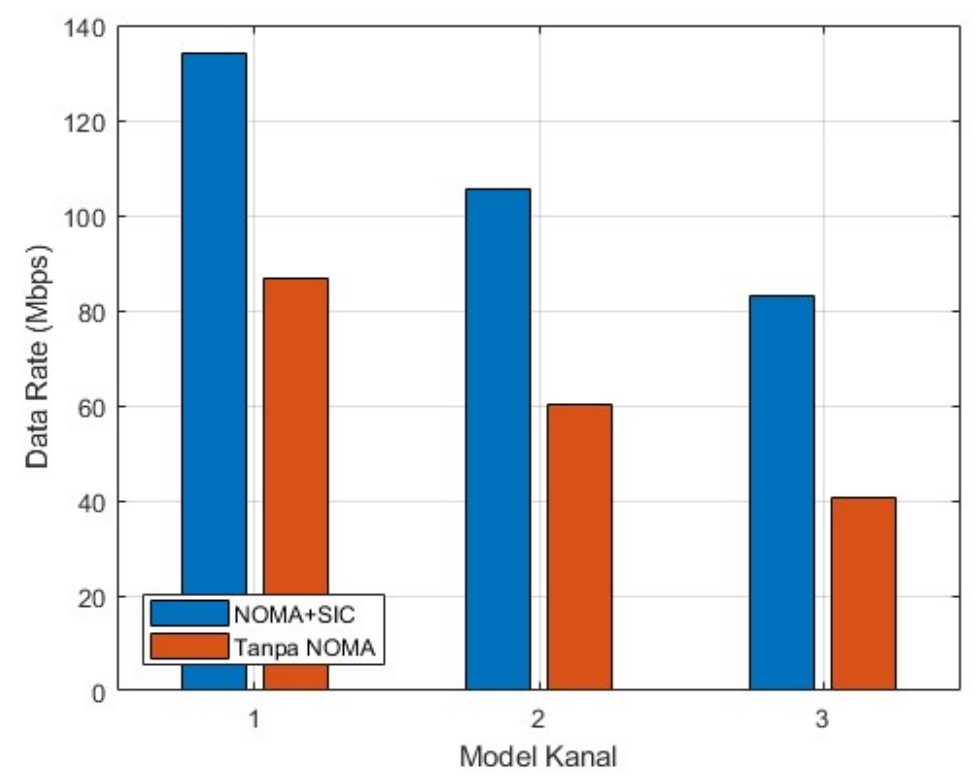

Gambar 6. Perbandingan Data Rate Sistem terhadap Permodelan Kanal.

Gambar 6 menjelaskan mengenai pengaruh kanal terhadap data rate yang dicapai dengan membandingkan kondisi kanal pada tiap user. Kanal ke-1 merupakan kanal yang terkena efek reflektor, pada penelitian ini user 1 dan user 2 berada pada kondisi kanal ini. User 3 dan user 4 berada pada kondisi kanal ke-2 yang merupakan kanal LOS. Sedangkan, pada kanal ke-3 yang merupakan kanal yang terkena efek shadowing terdapat user 5 dan user 6 . Hasil yang diperoleh pada penelitian ini menunjukkan bahwa kanal reflektor menghasilkan total rate yang lebih tinggi dalam sistem baik menggunakan NOMA maupun tidak yaitu sebesar $138 \mathrm{Mbps}$ dan 86 Mbps. Hal ini dikarenakan dengan penambahan reflektor pada sistem VLC sinyal yang diterima oleh user yang terkena efek reflektor mendapatkan sinyal dari multi-path.

\section{KESIMPULAN}

Berdasarkan hasil simulasi yang ekstensif menggunakan sistem NOMA-VLC dengan penerapan SIC pada kanal NLOS, teramati bahwa penggunaan NOMA-VLC mampu meningkatkan data rate. Berdasarkan peletakan posisi user, untuk user yang berada pada kanal NLOS reflektor menghasilkan sum rate sebesar 138 Mbps dan SNR yang paling baik dibandingkan dengan userlain pada kanal LOS dan kanal NLOS shadowing. Hal ini dikarenakan dengan penambahan reflektor terjadi pemantulan sinar cahaya yang menyebabkan user mendapat sinyal dari berbagai arah serta jika adanya penghalang antara sinyal dan user dapat mengurangi performansi dikarenakan penghalang dapat menyerap sinyal cahaya yang dikirimkan. Sistem NOMA-VLC dapat memberikan performansi yang lebih baik dibandingkan sistem VLC tanpa 
menggunakan NOMA karena dengan adanya superimposed pada transmitter membuat sinyal informasi yang dikirimkan dapat dilakukan secara bersamaan sehingga meningkatkan efisiensi spektral dan penggunaan SIC di sisi receiver membuat performansi menjadi lebih baik karena tidak ada interferensi antar sinyal user, oleh karena itu terjadi peningkatan total data rate sebesar 72\% dari 186 Mbps menjadi 321 Mbps.

\section{DAFTAR RUJUKAN}

Armstrong, J., Green, R. J., \& Higgins, M. D. (2012). Comparison of three receiver designs for optical wireless communications using white LEDs. IEEE communications letters, 16(5), 748-751.

Benjebbour, A., Saito, Y., Kishiyama, Y., Li, A., Harada, A., \& Nakamura, T. (2013). Concept and practical considerations of non-orthogonal multiple access (NOMA) for future radio access. 2013 International Symposium on Intelligent Signal Processing and Communication Systems, 770-774.

Dimitrov, S., Sinanovic, S., \& Haas, H. (2012). Clipping noise in OFDM-based optical wireless communication systems. IEEE Transactions on Communications, 60(4), 1072-1081.

Ghassemlooy, Z., Popoola, W., \& Rajbhandari, S. (2019). Optical wireless communications: system and channel modelling with Matlab\&. CRC press.

Guan, X., Yang, Q., \& Chan, C.-K. (2017). Joint detection of visible light communication signals under non-orthogonal multiple access. IEEE Photonics Technology Letters, 29(4), 377380.

Játiva, P. P., Azurdia-Meza, C. A., Cañizares, M. R., Zabala-Blanco, D., \& Montejo-Sánchez, S. (2020). Performance Analysis of OFDM-Based VLC Schemes in NLOS Channels. 2020 South American Colloquium on Visible Light Communications (SACVC), 1-6.

Kurniawan, P., Sujatmoko, K., \& Pamukti, B. (2019). Performance of OOK-RZ and NRZ Modulation Techniques in Various Receiver Positions for Li-Fi. 2019 IEEE International Conference on Signals and Systems (ICSigSys), 173-177.

Liu, C.-H., \& Liang, D.-C. (2018). Heterogeneous networks with power-domain NOMA: Coverage, throughput, and power allocation analysis. IEEE Transactions on Wireless Communications, 175), 3524-3539.

Marshoud, H., Kapinas, V. M., Karagiannidis, G. K., \& Muhaidat, S. (2015). Non-orthogonal multiple access for visible light communications. IEEE photonics technology letters, 28(1), 51-54.

Putri, N. A. Y., Hambali, A., \& Pamukti, B. (2019). VLC system performance evaluation with addition of optical concentrator on photodetector. 2019 IEEE International Conference 
on Signals and Systems (ICSigSys), 167-172.

Su, X., Yu, H., Kim, W., Choi, C., \& Choi, D. (2016). Interference cancellation for nonorthogonal multiple access used in future wireless mobile networks. EURASIP Journal on Wireless Communications and Networking, 2016(1), 231.

Tao, S., Yu, H., Li, Q., \& Tang, Y. (2019). Strategy-based gain ratio power allocation in nonorthogonal multiple access for indoor visible light communication networks. IEEE Access, 7, 15250-15261.

Tonapa, O., Rahmiati, P., \& Komba, D. (2014). Analisis Performansi Konektifitas Pada Jaringan Wireless Broadband di Bandung. ELKOMIKA: Jurnal Teknik Energi Elektrik, Teknik Telekomunikasi, \& Teknik Elektronika, 2(2), 162.

Wang, B., Dai, L., Zhang, Y., Mir, T., \& Li, J. (2016). Dynamic compressive sensing-based multi-user detection for uplink grant-free NOMA. IEEE Communications Letters, 20(11), 2320-2323.

Wang, C., Wang, L., Chi, X., Liu, S., Shi, W., \& Deng, J. (2015). The research of indoor positioning based on visible light communication. China Communications, 12(8), 8592. 